\title{
Human Rights Protection and the Question of Good Governance in Nigeria
}

\begin{abstract}
Nigeria is a signatory to several international human rights instruments, in addition to these, the Constitution of the Federal Republic of Nigeria 1999 (as amended) profusely contained provisions on the protection of human rights of peoples in Nigeria, yet violation of human rights still goes on in the country. The effects of the violations are grave and include loss of lives; loss of limbs or vital organs; loss of properties, loss of freedom, and loss of unhindered access to basic existential needs and so on. These violations are possible because the regime of good governance in all its ramifications is not yet in place. Bad governance is one of the recipes for massive abuse of human rights. The structures and institutions for the observance of good governance in Nigeria are in place, but they have been deliberately crippled by the successive governments. This paper submits that the nexus between good governance and the protection of human rights makes it mandatory that the enthronement of good governance is a must in Nigeria. This enthronement, in a sustainable manner is possible but it imposes a duty on all and sundry.
\end{abstract}

\section{Introduction}

The degree of human rights protection or abuse in a society is directly proportional to the quality of governance in that society. Most of the time, Nigerian as a nation has been plagued with bad, ineffective, indolent and corrupt governance at all levels of government. This has corrosive effects on both the public and private sectors of the society, that is, the public administration machineries including the administration of justice on the one hand, and corporate governance in the private sector on the other hand have been affected by the menace. Both in the public and private sectors, abuse of human rights go on with consequent negative impacts on the quality of life of the people. In such instances, it is the government that would be called upon for the enforcement of those rights.

The government has often failed to live up to expectation on occasions where the enforcement of human rights ought to be taken for granted. This is so since the enforcement machineries, government institutions and structures are performing below expectation. The structures have been deliberately weakened financially, the personnel staff are inadequate, the tools and necessary infrastructure are dated and few. The indices for measuring good governance is relegated to the background and ignored.

This paper examined some human rights issues in Nigeria against the backdrop of the quality of governance in the Nigerian society. It also briefly discussed the measuring yardstick for determining the quality of governance in a society. Comparison was made to what obtained in some other jurisdictions. segments:

This paper is discussed under the following

(a) a brief discussion of human rights as a concept;

(b) contemporary human rights issues in Nigeria;

(c) the institutions protecting human rights;

(d) a brief discussion of the concept of good governance;

(e) the link between human rights issues and good governance; and

(f) Conclusion.

\section{Human Rights as a Concept}

Human right is a dynamic concept. ${ }^{1}$ It connotes many things to many people and there are as many definitions of 
human rights as the number of human rights commentators. Views differ based on theoretical cleavages. The pure grammatical meaning of the concept was given in Black's Law Dictionary ${ }^{2}$ as 'the freedoms, immunities and benefits that according to modern values (especially at international level) all human beings should be able to claim as a matter of right in the society in which they live'. In addition to the dictionary meaning of the concept, the perceptions of a few scholars on the notion of human rights are briefly mentioned hereunder.

The learned writers, Daniel Tarantola ${ }^{3}$ et al., succinctly described human rights in the following words:-

In the modern world, human rights are often invoked to justify a variety of fundamental political, social, economic and cultural claims. The origins of rights (whether anchored in natural law, positive law, a theory of human needs, capabilities and flourishing, or some other theoretical position) and their justifications are diverse. There is, nevertheless, considerable international consensus about a central core of human rights claims, in particular those embodied in explicit international obligations accepted by nation states in the principal United Nations and regional human rights instruments adopted since world war 2 ...this is so notwithstanding the challenges of cultural relativism and the need for human rights to be realized in the specific contexts of different communities...

Human rights, according to Osita Eze, are the 'demands or claims which individuals or groups make on society, some of which are protected by law and have become part of the lex lata, while others remain aspirations to be attained in the future. ${ }^{4}$ opined that:

Seyi Leigh ${ }^{5}$ while quoting Chy Ben Ezenekwe

Human right is one of those legal concepts that defy a single acceptable definition from learned text writers and judges. Human rights are those rights that are inherent in our nature as human beings. The concept of human rights acknowledges that every single human being is entitled to enjoy his or her human rights without distinction as to race, colour, sex, language, religion, political, birth or other status ${ }^{\prime 6}$. The central figure in human rights is the human being, the protection of whose rights, whose respect and integrity deserve the highest attention.

Every human being has certain fundamental rights which governments must uphold and respect. This concept is rooted in most of the world's regions and cultures and is reflected in many legal systems. Human rights are part of the common heritage of all mankind without discrimination. These rights are common to mankind and they have a long history, many of them having their own origin in religious teachings. They have been formulated more fully than ever before and agreed to by all peoples from all parts of the world ${ }^{8}$. In a general sense, human rights are understood as rights which belong to an individual as a consequence of being a human being and for no other reason ${ }^{9}$. Human rights therefore, are those rights which one possesses by virtue of being a human being and one need not possess any other qualification to enjoy human rights other than the fact that one is a human being. ${ }^{10}$

Femi Falana, a human rights activist, is of the view that:

Natural theorists view human rights in the abstract, [and that] according to them human rights are the specie of rights which can be said to inherent in every human being. Since they are regarded as inalienable and immutable such right cannot be taken away from any person without affront to justice $^{11}$

Human rights cover a wide range of concerns. They do not merely incorporate civil and political rights, but economic, social and cultural rights as well. They also embrace a healthy environment, development and similar issues. The range is so broad that practically everything done to benefit humankind could be considered a human right. $^{12}$

Still on the concept of human rights, another scholar's observation is that:

Rights are a serious matter, they are much more than only justified claims on a desired state of affairs... they concern states' obligations to vulnerable individuals and communities. If human rights are to be more than simply words, they have to exist in a conducive ethical environment, in which people subscribed to the principle that certain basic dimensions of life, including the economic, the social and the political, be enjoyed by everyone, that these basic standards be respected by everyone in their interactions with others, and that states, both individually and collectively, respect these standards themselves, defend them against being destroyed by third parties, and fulfill them for people deprived of them $^{13}$

In one of the locus classicus cases on human rights in Nigeria, the case of KUTI v. AG FED \& Ors., ${ }^{14}$ the Supreme Court pondered over the nature and meaning of human rights; the court, per Kayode Eso, JSC ${ }^{15}$, asked a rhetoric question, 'but what is the nature of human rights ? ${ }^{16}$ and he answered the question as follows: 'it is a right which stands above the ordinary laws of the land and which is in fact antecedent to the political society itself. It is a primary condition to a civilized existence and what has been done by our constitution, since independence starting with the Independence Constitution, that is, the Nigeria (Constitution) Order in Council 1960, up to the present Constitution, that is, the Constitution of Federal Republic of Nigeria $1979^{17} \ldots$ is to have these rights enshrined in the 
constitutions so that the rights could be "immutable" to the extent of the "non immutability" of the constitution itself... ${ }^{, 18}$

Since human rights predates the constitution of nation states, little did the late music legendary, Fela Anikulapo Kuti ${ }^{19}$ knew that he was making jurisprudential statement when he sang that 'human right na my property, government can't dash me human right', though the song was in pidgin English ${ }^{20}$, it literally means that human rights are endowed by the creator in us and it is not what any particular government could issue out to anybody through governmental fiat. After all, you cannot give what you do not have, nemo dat quod non habet. The best that the government can do is to create an enabling environment that will not support unbridled violation of right.

The Supreme Court of Nigeria drew our attention to the fact that the term 'fundamental rights' was not distinctively defined elaborately anywhere in the Nigerian Constitution. In Fajemirokun v. Commercial Bank ${ }^{21}$ the court, per Muhammad JSC., while considering a matter brought before it which bothers on the enforcement of fundamental rights held that " neither the Constitution of 1979 nor that of 1999 has defined the term "fundamental rights", the Fundamental Rights (Enforcement Procedure) Rules.... which the Chief Justice of the federation made, pursuant to the power conferred upon him by sections 42(3) of the 1979 and section 46(3) of the 1999 constitutions assign the following interpretation to the term "fundamental right" to mean "any of the Fundamental Right provided for in chapter four of the constitution". ${ }^{22}$

It must be pointed out that the new Fundamental Rights (Enforcement Procedure) Rules ${ }^{23}$ abrogated the 1979 Rules and it expanded the interpretation of fundamental rights to include any of the rights stipulated in the African Charter on Human and People's Rights. It specifically provides that Fundamental rights "means any of the rights provided for in chapter four of the Constitution, and includes any of the rights stipulated in the African Charter on Human and People's Rights (Ratification and Enforcement) Act. ${ }^{24}$

This new Rules is commendable. It has expanded the frontiers and categories of rights over which one can now approach the courts to ask for redress upon any infringement or upon the belief that such right is about to be infringed. It has expressly taken rights that citizens and persons residents in Nigeria could enjoy beyond the borders of Nigeria to include rights recognized at the continental and global level. In essence, if some rights are not expressly provided for under Chapter four of the Nigerian Constitution, which is a domestic law, but such right is provided for by the African Charter on Human and People's Rights, a person could approach the courts in Nigeria to have such category of right redressed by Nigerian courts.

Some rights which are listed under the Fundamental Objectives and Directive Principle of State policy $^{25}$, which otherwise may be non justiciable, but which are now expressly stated as fundamental rights under the African Charter on Human and People's Rights ,now have unrestricted right of entry to the temple of justice to be adjudicated upon without being tagged non justiciable right(s).

Considering the ingenuity of litigants in Nigeria to subject a lot of issues to the entire gamut of judicial litmus test, one should surely anticipate interesting litigations in the near future on Constitutional issues such as the exact status of the new rules, whether it is part of the 1999 Constitution, whether it is in conflict with any provision of the 1999 Constitution and so on and so forth. On the one hand, some litigants are just interested in having their own day in court even if to test issues of law that has been settled over the years ${ }^{26}$, on the other hand such instances have always given the Nigerian courts opportunities to further contribute to our rich and growing human rights literature.

Fundamental human rights are posited as inalienable (individuals cannot lose these rights any more than they can cease being human beings); as indivisible (individuals cannot be denied a right because it is deemed a less important right or something non-essential); and as interdependent (all human rights are part of a complementary framework, the enjoyment of one right affecting and being affected by all others). ${ }^{27}$

The concept of human rights exists in three spheres: in the minds of the people, in ethical codes governing states' performance and in similar super-positive realms of justice, and ultimately, in national and international law. ${ }^{28}$

Fundamental rights are generally regarded as those aspects of human rights which have been recognized and entrenched in the constitution of a country. They are specially provided for to enhance human dignity and liberty in every modern state. In the Nigerian context, the terms 'human rights' and 'fundamental rights' are always used interchangeably. ${ }^{29}$

Chapters 2 and 4 of the Constitution of Federal Republic of Nigeria, 1999 are on the fundamental objectives and directive principles of state policy, and on human rights respectively. While some items under chapter 2 will qualify as human rights in some other jurisdictions and thus justiciable in those jurisdictions, they do not enjoy such status under chapter 2 of the Nigerian constitution, but the emerging trends of events points to some form of positive climatic change in the human rights environment. Attaining this atmospheric change will usher in a regime where the non justifiability clause will be thrown overboard and a new regime of human rights enthroned.

In the Republic of South Africa, there is constitutional protection for human rights under chapter 2 of the constitution. ${ }^{30}$ Chapter 2 is on the Bill of Rights. The constitution provides:-

S. 7

(1) This Bill of Rights is a corner stone of democracy in South Africa. It enshrines the rights of all people in our country and affirms the democratic values of human dignity, equality and freedom. ${ }^{31}$

(2) The state must respect, protect, promote and 


\section{fulfill the rights in the Bills of Rights. ${ }^{32}$}

Some rights which are considered not justifiable under the Nigerian Constitution are justiciable under the South African Constitution. These includes right to health care, food, water and social security. For instance, the South African Constitution provides as follows:

\section{S.27}

(1) Everyone has the right to have access to-

(a) Health care services, including reproductive health care,

(b) Sufficient food and water; and

(c) Social security, including, if they are unable to support themselves and their dependants, appropriate social assistance.

(2) The state must take reasonable legislative and other measures within its available resources, to achieve the progressive realization of each of these rights.

(3)No one may be refused emergency medical treatment.

\section{S. 29EDUCATION}

(1) Everyone has the right

(a) to a basic education, including adult basic education; and

(b) to further education, which the state, through reasonable measures, must make progressively available and accessible.

The Constitution of the Republic of Ireland ${ }^{33}$ also made provisions on the personal rights of people's. ${ }^{34}$ Like the South African Constitution, items which are regarded as non justiciable under chapter 2 of the Nigerian Constitution are justiciable in Ireland.$^{35}$ This constitutional development is worth emulating by Nigeria and other developing nations.

This segment of this paper is concluded on the note that human rights predates human beings, they are not divisible, they cannot be wished away and infraction of any of them will reduce the affected person to less than a human being. The constitution and the international human rights instruments did not give nor create those rights, they only guarantee them. Human rights are not absolute; they are restricted under certain conditions where the interest of public safety, public order, public morality and defense dictates such restriction in a democratic setting.

Irrespective of the theoretical meaning one gives to human rights, its protection, infringement and, or, extension to all categories of persons is a function of the level of development and quality of governance of the country. In Nigeria today, human rights related issues are the subject of many discourses, both official and unofficial. Some of those issues are the focal point of discussion in the next segment of this paper.

\section{Some Contemporary Human Rights Challenges in Nigeria}

The most critical human rights challenges in Nigeria and most developing countries of the world today are related to existential issues threatening the very existence of humanity such as food, clothing, shelter, disease and ignorance. These problems are inextricably tied to the enjoyment of human rights and they are offshoots of bad governance. Existential issues accompanied by bad governance inevitably results into abuses as opposed to the protection of human rights.

At the African continental level, 340 million people or half the population lives on less than one US dollar per day. The mortality rate of children under 5 years of age is 140 per 1000 , and life expectancy at birth is only 54 years. Only 58 per cent of the population has access to safe water. The rate of illiteracy for people over 15 is 41 per cent... ${ }^{36}$ In spite of this awful statistics generated over one and a half decades ago, the continent blessed with abundant natural resources has remained largely undeveloped due to corruption and mismanagement which are manifestations of bad governance. ${ }^{37}$

At the national level, the situation was not different. In year 2016, the global human development index of the United Nations ranked Nigeria the $152^{\text {nd }}$ position in the world out of 188 nations. ${ }^{38}$ This parlous position has grave implications on the enjoyment and protection of human rights in Nigeria. This was not due to dearth of abundant human and human resources in Nigeria but it was the result of bad governance at its best. In the midst of plenty, Nigerians are lacking those very things that are necessary for the enjoyment of quality existence as human beings. ${ }^{39}$

Poverty is a contemporary human right issue that requires urgent attention. It is a great impediment to the enjoyment of basic rights by individuals. In the words of John C Mubangizi ${ }^{40}$, 'poverty is not new. It is not a recent affliction of human kind. It has always been with us... of all the social phenomena that have a significant impact on human rights, poverty ranks highest... some have actually agreed that poverty is in itself a violation of human rights' It is important to note that there are secondary human rights challenges other than existential ones mentioned above and they affect the enjoyment of human rights in Nigeria, they include but are not limited to the followings:-

(a) Armed robbery. This one happens at any hour of the day, the robbers operate with reckless impunity on the highways, on the side streets, at religious centers, at the arena of police stations, in individual homes and in fact at anywhere with or without notice. When armed robbery takes place, the victims are left traumatized, sometimes raped, maimed or killed out rightly. This is a serious human right challenge. A caveat has to be sounded here that armed robberies occurs in both developed and developing countries, it is not a phenomenon restricted to countries with bad governance alone, but it is a violation of rights of the victims by the robbers. 
(b) Terrorism especially those ones carried out under the cover of religion; such as the Boko Haram sect in the northern part of Nigeria. This act is a crime against humanity; it is an international crime and a grave violation of the rights of the victims. The female students of government secondary school in Chibok, Nigeria who were forcefully abducted from the school have not all been released up to date. While conceding that the government was not the terrorist itself, it took a long time for the Nigerian government to shake off the lethargy of inaction and confront the terrorist headlong.

(c) Greed and brazen acts of corruption on the part of leaders. The stupendous amounts of government monies that are reported as being returned to the coffers of the government by corrupt government officials and their cronies is water watering. These are funds meant for the execution of specific projects that ought to make life better in Nigeria. The Nigerian government is culpable in this respect. Depletion of the government purse has affected the release of funds that is necessary to strengthen the institutions which will ensure the protection of human rights.

(d) Extra judicial killings. This is done by the law enforcement agencies and by unscrupulous evil minded persons who murder fellow human beings for ritual purposes in the country. The violation of a person's right to life in any unlawful, unexcused or unauthorized manner constitute extra judicial killing and it is an irredeemable violation of fundamental human right.

(e) Militancy in the Niger Delta region of Nigeria has resulted in so many abuses of human rights such as the abduction and kidnapping of expatriates and Nigerians alike on a regular frequency, vandalization of oil and gas pipelines, pollution of the environment, illegal proliferation of arms in the region and other associated social vices. This is gross violation of human rights.

(f) Executive lawlessness. The refusal, neglect and omission of the government to act in accordance with the provisions of the constitution and in utter disregard to the sufferings of the people are a violation of rights.

(g) Legislative judgment. ${ }^{41}$

(h) Disrespect for court orders.

(i) Illegal or wrongful withholding of workers' wages, salaries and emoluments other than in accordance with due process of the law or of pensions and gratuities of retired workers are another class of human rights abuse. A person whose means of subsistence is withheld cannot enjoy any right guaranteed under the constitution.

(j) Lack of unhindered access to basic things of life such as potable water, good environment, electricity, good roads, elementary education, etc.

(k) Lack of prompt, effective, efficient and adequate framework and equipment necessary to rescue people in distress and during emergencies;

(1) Acts of ethno-cultural and religious intolerance; and of course the latest addition to the growing list of items on the festering sore of the continent-

(m) Kidnapping. This is a crime that appears to be attractive to criminals in Nigeria today. It is a thriving source of illegitimate money. It initially started as with the kidnapping of expatriates working with oil companies in the Niger-Delta region of the country when oil workers are kidnapped for ransom, but now, this ignominious act had spread to all nooks and crannies of the country, the hinterland inclusive. They now kidnap babies on their way to crèche, parents, grandparents, old people, young ones, politicians, journalists, actors, etc. anybody is a potential victim of kidnap today in Nigeria.

The above mentioned human rights challenges are just a few of the ones confronting people and they have the effect of setting the hands of the clock back in the arena where human rights deserve to be of upheld and enjoyed. They are clear indices of systemic failure which are attributable to bad governance.

There is no justification or excuse for committing any of the above mentioned acts, but it appears a lot of those who engages crime of that magnitude take to crime because they want to get rich quick; they felt that the enormous wealth of this country is not being equitably managed because the leaders have failed the country through their gluttonous and insatiable appetite for stealing public funds and properties; they want to subvert due process; they are frustrated and that there are loopholes in the system that they could exploit and get away with it on a platter of gold. We submit with due respect that if a system is such that all people, including criminals knew very well that the system has adequate facilities to promptly detect crimes, to transparently punish offenders and to prevent crimes, most of the crimes will be on the downward plunge.

Many people are incapable of making informed decisions, partly because they had been brain washed by one leader or another, the leaders could be political, economic, religious and sometimes traditional leaders. This act more often than not results in gross violation of the right(s) of their followers. The case of a religious leader by the name Rev King is still fresh. He is the one reported to have set some of the members of his congregation ablaze as punishment for disobeying his rules.

An attribute of bad leadership is that capacities for upholding truth, justice, equity and fairness will collapse and go under thus the greatest happiness of the greatest number becomes a mirage.

A serious human right issue in Nigeria is religious intolerance. It must be noted that series of religious crisis in Nigeria had resulted in the loss of lives, limbs and properties. The Boko Haram incidence of year 2009 is still fresh in the memories of people. This incidence is one where a certain Mohammed Yusuf a 39 year old Islamic militant led his gang of religious militants to attack and 
burn down police stations massacre innocent citizens on the ground that their sect is opposed to people with western education and values. ${ }^{42}$

Ethno - cultural intolerance is equally a disturbing issue which had resulted in and still responsible for brothers senselessly killing and maiming one another. The Amuleri -Uguleri crisis, the Ile Ife - Modakeke crisis, the Hausa Yoruba crisis in Sagamu, the intractable and ever recurring Jos crisis are just a few of those sad events that left sour tastes in the mouth and indelible scars in the memories. These crises are traceable to failure of leadership.

Leaders of the political class have given people a lot of cause for concern with their do or die attitude towards electoral matters. This has in a grave manner impacted negatively on the human rights posture of Nigeria. In Ehinlanwo v. Oke $e^{43}$ the Supreme Court frowned at the bad attitude of politicians to election and the court held that " the stark realities of the Nigerian situation particularly as it relates to the attitude of the political class which sees election into any position as a matter of life and death and is consequently ready to do anything possible to attain the ambition..., ${ }^{44}$

One cannot but remember the foiled attempt by a 25 year old Nigerian, Abdul Mutalab who on 25 December 2009, attempted to blow up an aircraft with all the passengers on board. He was alleged to have been influenced and trained by a certain religious group who has reservations about others. He is currently undergoing trial in a United States of American court of law.

In Nigeria there are several cases of unresolved high profile murder of citizens such as the late Dele Giwa; Pa Alfred Rewane ; Chief Bola Ige ; Dipo Dina; the son of Chief Olu Onagoruwa while the Chief was the Attorney General of the Federation, etc just to mention a few.

There are several cases of extra judicial killings by the police too numerous to recount. The Supreme Court recently suggested that police men should be properly checked to ensure that they are fit and proper to handle rifles before they are posted to their duty posts. ${ }^{45}$

The court made that suggestion based upon the facts of the case of Oludamilola v. State ${ }^{46}$ where the appellant in the case, a police officer shot a revolver pistol at the deceased who had gone to a police station in sympathy with an arrested person. There was evidence that prior to the incident, the appellant and another colleague had been drinking illicit gin.

Niki Tobi JSC, in the case held inter alia that:

This is a bizarre case of murder of an innocent citizen by a police officer. Visiting the police station is not an offence. Visiting the police station in sympathy with an arrested person is not also an offence and so the appellant had no right to shoot Solomon to death. There is evidence that the appellant was drunk at the time he shot the deceased. This brings to the fore the need to check police officers immediately before and during duty of drinking alcohol. I am sure that if the appellant was checked before he was posted for duty, there was the possibility of dropping him from the beat.

In Yaki v. State ${ }^{47}$ the court described actions of policemen who engage in extra judicial killings as callous and irresponsible. The few contemporary human rights issues ravaging our nation today are manmade and solutions to them will surely come from man himself and this means we all have a duty to restore human rights back to its rightful place. Let all people play their roles well in accordance with the law.

\section{Some Human Rights Instruments and Institutions Protecting Human Rights and Human Rights Issues}

There are various documents and institutions both at the national and international levels whose sole aim is the protection and advancement of human rights. The institutions in most countries are both governmental and non-governmental organizations. At the apex point among governmental institutions protecting human rights we have the various courts of justices in Nigeria. In recent years, one are of the view that the Nigerian courts have proved and are still proofing their mettle in the discharge of their assignments in the quest to uphold justice to all and the protection of rights of peoples.

There are various documents at the national, continental and global levels promoting the rights of peoples. They include but are not limited to The Universal Declaration of Human Rights, The United Nations Charter, The Constitutions of various countries and several Bills Of Rights.

In Nigeria, the National Human Rights Commission $^{48}$ is established for the protection of human rights, dignity and freedoms. ${ }^{49}$ The commission was also designed by the government as a forum for public enlightenment and dialogue on and to limit controversy and confrontation over allegations of human rights violation by public officers and agencies and to reaffirm the sacred and inviolable nature of human and other fundamental rights. ${ }^{50}$

The functions of the Commission are succinctly stated in section 5 of its enabling statute as follows :

(a) Dealing with all matters relating to the protection of human rights as guaranteed by the Constitution of the Federal Republic of Nigeria, the African Charter on Human and People's Rights, the United Nations Charter and the Universal Declaration on Human Rights and other International Treaties on human rights to which Nigeria is a signatory;

(b) Monitor and investigate all alleged cases of human rights violation in Nigeria and make appropriate recommendation to the President for the prosecution and such other actions as may deem expedient in each circumstance;

(c) Assist victims of human rights violation and seek appropriate redress and remedies on their behalf;

(d) Undertake studies on all matters pertaining to human rights and assist the Federal Government in the formulation of appropriate policies on the guarantee of human rights; 
(e) Publish, from time to time, reports on the state of human rights protection in Nigeria;

(f) Organize local and international seminars, workshops and conferences on human rights issues for public enlightenment;

(g) Liaise and co-operate with local and international organizations on human rights with the purpose of advancing the promotion and protection of human rights;

(h) Participate in all international activities relating to the promotion and protection of human rights;

(I) Maintain a library, collect data and disseminate information and materials on human rights generally; and

(j) Carry out all such other functions as are necessary or expedient for the performance of its functions under the Act.

The effort of the government at setting up the commission is worthy of commendation. We submit that the commissions functions are unique to it as a government agency, the functions are equally fundamental to the establishment of a sustainable human rights regime in Nigeria provided the government does not frivolously interfere in the internal affairs of the commission and the commission is not starved of funds at the right time that funds are required.

In Europe, the European Court of Human Rights located in Strasbourg is an institution saddled with the responsibility of entertaining human rights matters brought before it by European and residents of Europe. The equivalent of the Strasbourg court in Africa is African Commission on Human and Peoples' Rights. ${ }^{51}$

In Nigeria, the new Fundamental Rights (Enforcement procedure) Rules have provided a very conducive environment for the protection and enjoyment of fundamental human rights. The Rules contained copious provisions which have removed unnecessary impediments on litigant's access to court on fundamental rights issues. This point is buttressed by some of the provisions of the rules especially in its per-ambulatory section reproduced hereunder:follows ${ }^{52}$ :-

'The overriding objective of these Rules is as

(a) The Constitution, especially Chapter four as well as the African Charter, shall be expansively and purposely interpreted and applied, with a view to advancing and realizing the rights and freedoms ${ }^{53}$ contained in them and affording the protections intended by them;

(b) For the purpose of advancing but never for the purpose of restricting the applicant's rights and freedoms, the constitution shall respect municipal, regional and international bills of rights cited to it or brought to its attention or of which the court is aware, ${ }^{54}$ whether these bills constitute in themselves or form parts of larger documents like constitutions. Such bills include: i. The African Charter on Human and People's Rights and other instruments (including protocols) in the African regional human rights system

ii. The Universal Declaration of Human Rights and other instruments (including protocols) in the United Nations human rights system

(c) $\ldots$

(d) The court shall proactively pursue enhanced access to justice for all classes of litigants, especially the poor, the illiterate, the uninformed, the vulnerable, the incarcerated, and the unrepresented ${ }^{55}$

(e) Encourage and welcome public interest litigation ${ }^{56}$ in the human rights field and no human right case may be dismissed or struck out for want of locus standi $i^{57}$

(f) The court shall in a manner calculated to advance Nigerian democracy, good governance, human rights and culture, ${ }^{58}$ pursue the speedy and efficient enforcement and realization of human rights

(g) Human rights suits shall be given priority in deserving cases. Where there is any question as to the liberty of the applicant or any person, the case shall be treated as an emergency. ${ }^{59}$

The public interest litigation ${ }^{60}$ now captured by the new rules is one of the things that Hon Justice Bhagwarth of India had preached for so long a time. He is an advocate of this advancement in law. Also, under the new rules, an application for the enforcement of fundamental rights shall not be affected by any limitation statute whatsoever. ${ }^{61}$

No doubt the above quoted provisions are evidence of fundamental and landmark milestones put in place by the judiciary in Nigeria to advance the protection, enforcement and enjoyment of human rights. It is submitted with respect that these new rule is a reflection of what is right, proper, just and desirable, it is a reflection of the human rights standard that the United Nations from all nation states. This is marvelous manner in which the Judiciary and its leadership in Nigeria had advanced human rights of the people under the Nigerian jurisprudence. This time tested point was again reiterated by the Supreme Court when Oguntade JSC ${ }^{62}$ held recently in Longe v. FBN ${ }^{63}$ that 'let me say with all the necessary force and emphasis that when the law vests a right on a citizen, a court of law will resolutely resist any attempt and by whatever method to deny the citizen the enjoyment of the right conferred by law'. The Supreme Court is not alone in this resolve to put human rights issues where they properly belongs, that is, the fron seat, the Court of Appeal as well has always been sounding it loud and clear to all that human rights and democracy are intertwined and that a robust human rights regime will naturally produce a well nourished democracy. This was emphatically made by the Court of Appeal in the case of Onyirioha v. IGP $P^{64}$ This again is commendable on the part of the judiciary in its quest to uphold human rights in Nigeria. 
The South African Constitution ${ }^{65}$ in the protection and strengthening of human rights in that country provides that its bill of rights 'is a cornerstone of democracy in South Africa. It enshrines the right of all people in our country and affirms the democratic values of human dignity, equality and freedom, ${ }^{66}$

Some of the other human rights instruments protecting human rights of persons includes but are not limited to the followings:-

i. European Convention on Human Rights and fundamental freedoms ${ }^{67}$;

ii. Universal Declaration of Human Rights ${ }^{68}$; The Universal Declaration of Human Rights has been commented on as a document 'which does not in itself constitute a binding document [but] lays down rules which irrespective of whether they are embodied in a binding document or not, are binding as customary international law.... ${ }^{69}$ Although the Universal Declaration of Human Rights is a General Assembly resolution and not binding per se, it can be argued that its acceptance by the overwhelming majority of UN member states has made it binding as part of customary international law. ${ }^{70}$ The human rights principles contained in international human rights instruments as adopted and proclaimed can be binding on states without specific assent on the part of states, legal positivism offers no escape from civilized standards. ${ }^{71}$

iii. International Covenant on Economic, Social and Cultural Rights; ${ }^{72}$

iv. International Covenant on Civil and political Rights ${ }^{73}$

v. International Convention on the Elimination of All forms of Racial Discrimination $;^{74}$

vi. Convention on the Elimination of All forms of Discrimination against Women; ${ }^{75}$

vii. Convention against Torture and other Cruel, Inhuman or Degrading Treatment or Punishment, ${ }^{76}$

viii. Convention on the Rights of the Child $;^{77}$

ix. European Social Charter; ${ }^{78}$

x. American Declaration of the Rights and Duties of $\operatorname{Man} ;{ }^{79}$

xi. American Convention on Human Rights $;{ }^{80}$ and

xii. African Charter on Human and Peoples' Rights, ${ }^{81}$ just to mention a few human rights instruments. ${ }^{82}$

\section{The Concept of Good Governance}

The law had placed a heavy duty on nation states and their organs to ensure that human rights are respected, protected and fulfilled. 'The state exists for the well being of their inhabitants...the social function of states is to ensure the ability of people to live, since the social purpose of the state is to enable its citizens to live, then it makes sense to recognize that social purpose as a right of each person... ${ }^{83}$
States as abstract jurisprudential entities discharges this duty through human elements ${ }^{84}$ who assume leadership positions in their nation. A leader for our purpose here includes those who are in administrative, executive, judicial and legislative organs of a state. We equally have people who occupy economic, educational, cultural, social and religious positions and have people under them as their followers, they too are leaders and they have a duty to uphold, protect and preserve the human rights of those under them.

There is no universally accepted definition of "good governance", the popular usage of the term comprehends how a given country is governed; how the affairs of a state are administered and regulated and how a nation's political system functions in relation to the management or conduct of public affairs. It also embraces how national resources are managed and how relations among the state, citizens and the private sector are regulated. ${ }^{85}$

Good governance encompasses a variety of items used as yardstick for its measurement in any society. The items for measuring it include the ones listed by Lysias Dodd Gilbert and Fidelis Allen ${ }^{86}$ as follows:

i. Accountability of public office holders with regards to public funds.

ii. Transparency in public policy and decision making processes.

iii. Predictability in government behaviour.

iv. Openness in government dealing and effective communication flow between government and the governed, and

v. Adherence to the rule of law.

Good governance according to another scholar ${ }^{87}$ was commented on as a concept that involves enthronement of a democratic government, which guarantees equal participation of all citizens in governance; provision, promotion and sustenance of the rule of law; provision and protection of the constitution; promotion and protection of the fundamental human rights of the citizens; provision and sustenance of the freedom of the press; availability of a transparent, accountable and participatory governance at all levels of government; regular, free and fair elections; as well as provision of basic amenities, such as, portable water, electricity, qualitative education, healthcare delivery, good roads, among others. Triumvirate of Democracy, the rule of Law and Good Governance.

The implication of the above is that in the absence of good governance a nation state cannot achieve any sustainable development neither can the 
people enjoy the protection of human rights. ${ }^{88}$ Good governance is one of the millennium development goals of the United Nations and it imposes a positive duty on nation states to strive to achieve it. ${ }^{89}$

This obligation on leaders was commented upon by the learned writers, Daniel Tarantola, et al., as follows:that 'first, states must respect human rights, which requires governments to refrain from interfering directly or indirectly with the enjoyment of human rights. Second, states must also have the obligation to protect human rights, which requires governments to take measures that prevent no-state actors from interfering with the enjoyment of human rights, and to provide legal and other appropriate forms of redress which are accessible and effective for such infringements. Finally, states have the obligation to fulfill human rights, which requires states to adopt appropriate legislative, administrative, budgetary, judicial, promotional and other measures towards the full realization of human rights, thus creating the conditions in which persons are able to enjoy their rights, fully in practice.... ${ }^{90}$

The common global trend nowadays is for nation states to jettison authoritarianism or any form of dictatorship and instead embrace democracy. Truly democratic leaders create conducive environment for human rights to thrive. Leaders must be democratic, but what do we mean by democracy itself?

Democracy itself 'is a complex concept that is closely related to multi partysim and elections'. ${ }^{91}$ It has acquired different, even contradictory meanings. It has been used and abused to such an extent that defining it is a challenge ${ }^{92}$. Two major conceptions of democracy may lead to confusion about the way in which democracy should be defined or the basis according to which countries should be adjudged democratic or not. There is indeed a minimalistic and a maximalistic conception of democracy. ${ }^{93}$

The point had been made that 'it is important for the leadership of a state nation to do more than just holding regular elections, it is not just enough for international institutions to support the leadership of a state nation, such leaders must also be "held accountable for their actions to ensure that they do not slide back into authoritarianism and that corruption and nepotism do not eat away at the fabric of society. Strong civil society participation and activism locally and internationally will often help in this regard"...one can deduce that without eternal vigilance from all sectors of society, even states with a good democratic tract record and strong constitutional institutions run the risk if backsliding into authoritarianism and disrespect for the basic rights of citizens... ${ }^{94}$

While commenting on leadership in human rights - leadership for the whole community, the Chairperson of Equal Opportunity Commission, Fiona Smith ${ }^{95}$ postulate that:

We should have brave and courageous leaders...leaders should draw inspiration from the grassroots community... the society changes because people are prepared to push for change, because people have the courage to call for change, because leaders make it happen.... All leaders need heart, courage, brain... and followers..Without other people, there is no leadership. Leadership is not a set of qualities in any individual...leadership must be earned and its something that goes on between people...leadership exists only in relationships and only in the imagination and perception of that group of "followers". No matter how charismatic someone may be, there's no leadership unless a group of people are influenced to act, because leaders need the group, in that sense, leadership is a relationship of equals.... We need leaders who show by their own attitudes and actions how everyone else should behave...

Leaders in government have a duty to build, sustain and promote a culture of human rights. Leaders in government should know that by virtue of their oath of office they have a duty to uphold the constitution of their country. Upholding the constitution may be a mere abstract term to a people who lack good roads, pipe borne potable water, good jobs, prompt payment of salary for work done, adequate health care system, conducive environment for sustainable socio-economic growth, free and fair elections, social security, sanctity of life and the respect for basic fundamental human rights of people. A true leader in political office - presidents, governors, local government chairmen, federal ministers, state commissioners and others elected or appointed into political offices as leaders have a responsibility to the led to accomplish the above and many more. A leader is a person in an utilitarian position of authority, clothed with power by the led and he has the power to influence things positively for the general benefit of the group that is being led. Leaders are however subject to a higher power which checkmates them whenever they want to transcend their bounds, if they are not subject to some form of ground norm the likelihood of the power in them intoxicating and corrupting them is there. A good leader respects the process that produced him. A true leader in government will uphold the tenets of good governance as highlighted above in other to uplift the human rights of the governed.

\section{The Link Between Protection of Human Rights and Good Governance}

It is a denial of human rights for a people not to enjoy good governance. The link between human rights and good governance is very strong; one ensures that the other thrives; the two of them mutually coexist. One of the yardsticks for gauging good governance is the respect for rule of law. Human rights are an integral part of rule of law. Good governance must therefore embrace unalloyed respect for human rights. Leader at all levels must not engage in anything contrary to the basic standards stipulated in any international human rights instrument. After all it had been posited that 'human rights today play an important role in shaping public policies, programs and practice aimed at improving actual and potential individual and social 
welfare'. ${ }^{96}$

Ignorance on the part some leaders about the existence of rights is a big challenge that has to be confronted by our leaders so that we the led would better know how to enjoy our rights. The point had been made by a scholar, Cecilia Median ${ }^{97}$ when she opined that there must be a community which has knowledge of the existence of human rights to a degree that allows it to exercise direct pressure on the authorities with respect to specific...observations or is able to exercise constant pressure by sheer presence, in such a way that the authorities of the state do not dare to comply with their human rights obligation... we need to educate people about human rights; we need to organize civil societies to keep constant watch over the conduct of rulers, we need to develop national mechanisms. The more we progress in this task, the easier it will be to lessen the number of human rights violations... ${ }^{98}$

A favorable human rights environment ultimately leads to good governance and development of a state, this in turn results in improved standard of living, higher life expectancy for the citizens, and improved infrastructure for the people. It is sad that in most part of Africa, poverty still reigns supreme, leaders violate the rights of the led with reckless impunity, state funds meant for development are embezzled and squandered, salaries are poor and sometimes not paid on time, people live below poverty line, state apparatus are sometimes turned against the citizens as instruments of oppression, and more often than not, conflicts is the end result of these unfortunate situation of things. There is 'empirical finding that a rise in human rights violations often precedes conflicts or massive human right violations... ${ }^{99}$, This entire gory picture is as a result of bad governance. Bad governance is a violation of human right.

Hillary Clinton's parting remarks to the Nigerian nation when she visited the country almost a decade ago still rang bells in our ears. She compared state of things in Nigeria with that of another African nation, Botswana and she remarked that 'being a sovereign nation, it is left to you, Nigerians, to decide whether to learn from Botswana example or not. Botswana has a vibrant democracy and a stable economy.... ${ }^{100}$ This charge must be taken seriously by Nigerian leaders. Nigeria does not have to wait until another Hillary Clinton comes around to the country and tells us to do the proper thing.

In the year 2003, African leaders, having learned from their own experiences that peace, security, democracy, good governance, human rights and sound economic management are conditions for sustainable development boldly declared their intention to change the picture from a gory one to a pleasant one. ${ }^{101}$ The document of declaration is The New Partnership for Africa's Development (NEPAD) and the document among other things requires African leaders to take responsibility for 'promoting and protecting democracy and human rights in their respective countries and regions, by developing clear standards of accountability, transparency and participatory governance at the national and sub national levels'. ${ }^{102}$
In the realization of human rights, it is incumbent on the state governments to put in place clearly identifiable bench marks, time frames within which facilities for enjoyment and no violation of the rights must be in place. Our humble suggestion is that democratic leaders should be encouraged to embark on capacity building while in office so that basic democratic values and human rights would be sustained in their society. According to Sandra Liebenberg ${ }^{103}$ 'without this plan of action, there is a real risk that policy commitments will simply remain noble sentiments on paper.'

There is a strong link between democracy, governance, human rights and poverty. The link has been described as the "basis of a largely complex but extremely important relationship. ${ }^{104}$

Leaders in Nigeria, in Africa, and in developing countries must embrace good governance as a panacea to trampling on the rights of peoples. 'Good governance is a term that 'is taken to encompass... effective government, the implementation of a range of liberal macro-economic policies, sound and forward looking leadership, the absence of corruption, and national and regional political and social stability' As such, good governance is a concept that can be used as a means test for the success and potential of economic policies and reforms. Take together, these definitions assume that not only are democracy and good governance pre-requisites for effective protection of human rights but that state polices intended to combat poverty must themselves be democratized. ${ }^{105}$

Still on good governance, Melvin L. Manbo \& G. G. Komboni ${ }^{106}$ postulated that the older and more restricted conception of governance as efficiency in economic management has evolved into a broader understanding of the way in which leaders exercised power and authority in an effective and inclusive manner to advance the cause of human rights. As the United Nations has correctly observed:, 'Human rights are inextricably linked with democratic governance. They both require people conscious of their rights and duties, appropriate institutional arrangements, and the existence of a democratic civic culture that applies both to issues of national importance and to those of everyday life. The sense of belonging to a community is nurtured by individual responsibility and by a collective observance of democratic principles. From this perspective, the unrestricted respect and defense of human rights constitutes the foundation of an equitable and participatory society in which everyone helps to achieve the common good, and in which individualism and competition are balanced by social awareness and solidarity ${ }^{107}$

Hon Justice Mobolaji Ayodele $\mathrm{Ojo}^{108}$ opined that in contemporary times, socio-economic reformers have formulated what may be regarded as universal indices and parameters for measuring the level of development of a state, now encapsulated in the concept of good governance. Justice Ojo then defined governance as the dynamic interaction between people, structures, processes and traditions that support the exercise of legitimate authority 
in provision of sound leadership, direction, oversight and control of an entity in order to ensure that its purpose is achieved, and that there is proper accounting for the conduct of its affairs, the use of its resources, and the results of its activities. ${ }^{109}$

In this milieu, democracy is now conceived not only as an end in itself but also as a means to political, economic and social rights. Human rights and democratic governance are inextricably and mutually reinforcing and share many core principles such as participation, accountability, transparency and responsibility. Indeed human rights need a conducive and enabling environment, in particular appropriate regulations, institutions and procedures framing the action of the state. ${ }^{, 110}$

In a practical sense democracy, rule of law and respect for human rights are indivisible and interdependent because democracy without human rights and the rule of law is oppression, human rights without democracy and the rule of law is anarchy and the rule of law without democracy and human rights is tyranny Corruption is the enemy of good governance. The exact opposite of good governance is the scourge of corruption, which has been defined by the United Nations as; the abuse of entrusted public power for private benefit. ${ }^{111}$

Corruption weakens the accountability of state officials and reduces transparency in the work of state institutions...., it is subversive of any country's political system.., it is a threat to the rule of law and the administration of justice.. the implementation of a country's laws as well as efforts to reform them are impeded by corrupt judges, lawyers, prosecutors, police officers, investigators and auditors.. Corruption has a negative impact on the realization of human rights in that corrupt practices divert funding aimed at social services... Corruption undermines the government's ability to deliver an array of services, including health, education and welfare services. ${ }^{112}$

The Nigerian government is fighting the scourge of corruption on a frontal level. The efforts of the Independent Corrupt Practices and other Related Offences Commission ${ }^{113}$, The Economic and Financial Crimes Commission, ${ }^{114}$ The National Drugs Law Enforcement Agency, The Code of Conduct Tribunal, are just some of the efforts along this line.

To enjoy human rights, good governance is a sine qua non, the bond between human rights and leadership is very strong. One has a direct influence on the other.

\section{Conclusion}

This paper has attempted, within its own limitation to discuss the concepts of human rights, good governance and the link between the two. ${ }^{115}$ No doubt there is a very strong nexus between good governance and the protection of people's fundamental rights. Rights could be infringed with reckless impunity in an environment where bad, inept and corrupt leaders are in the reins of power. We all have a duty to prevent power from getting to the wrong hands if we do not want our rights to be trampled upon the more; we are the leaders and masters of our faith as a people and the future starts today to ensure that things are done properly in accordance with collectively agreed procedure. Due process must be complied with.

At the level of the African continent, this paper concludes that the African peer review mechanism ${ }^{116}$ is a commendable framework that has the capacity to check erring leaders from going astray, the mechanism should be encouraged and utilized to the maximum.

At all levels, it is important that we should collectively prevail on all organs, sectors, peoples, leaders and institutions of governance to comply with, and act in accordance with human right standards, comply with decisions of courts and to shun disobedience of court orders. This will go far in the enthronement of a sustainable human rights culture in Nigeria.

Governments and all leaders must cultivate the habit of regarding the various human rights institutions as partners in the promotion and protection of human rights rather than as opponents ${ }^{117}$ this move, we suggest, has the propensity to lead to a unified fight against any attempt to violate the right of anybody or group of peoples.

The government must not see itself as an island of some sort. Government officials and leaders at all levels must interface with the led. They are to serve the people, to see to the welfare of the led and not to have the warped and misconceived opinion that they are above the led. Leaders must establish and engage channel of dialogue, periodically, between them and the people whom they govern. This is an attribute of participatory governance which if properly utilized will take unnecessary heat and misinformation off the government. The right of the people to be heard in decision making process would have been satisfied.

The state and its organs, institutions and agencies must live up to their obligations under the various human rights instruments, their domestic constitutions including those sections of the constitutions on what is called the non justiciable sections. ${ }^{118}$

There is need for all of us to rebuild the culture of human rights. The leadership must appreciate the everyday existence of the people. Human rights are not acquired in the abstract, they are built on the on the capacity to transform the lived reality. ${ }^{119}$

Again at the continental level, there is an urgent need in Africa to put into action the new political will of African leaders as contained in clauses 6 and 43 of the NEPAD document into action. Clause 6 inter alia urges leaders to be bold, imaginative and mobilize available resources and to use them properly in a way that is genuinely committed to sustained human development effort and poverty eradication. Clause 43 on the other hand recommends accountability on the part of governments supporting a culture of human rights and popular participation.

Human rights now transcend what obtains within the borders of a country, it is now of international concern and interest to the rest of humanity. This is to sound a note 
of warning to leaders who may be nursing the ambition of romancing with the illusion of getting away with bad governance to have a re think. Any leader who encourages human rights violation within his jurisdiction should now know that he cannot escape the long arms of the law. He may be able to hide from the long arms of the law for some time but cannot hide forever. The list of former leaders appearing before various courts of justice ${ }^{120}$ to account for their acts and or omissions while in office, is growing by the day, 'the promotion and protection of all human rights is a legitimate concern of the international community certain human rights have achieved the status of jus cogens, or principles from which there can be no derogation. ${ }^{121}$

On a final note, leaders have a duty to adopt a pragmatic approach that will strengthen human rights institutions. They should stop paying mere lip service to human rights issues. The yardsticks for measuring good governance must be complied with at all times at all levels of government.

\section{Footnotes}

M. O. Ogungbe, Foreword to Tony Nwazuoke, Introduction To Human Rights Law, Copycraft Int. Ltd., Abakaliki(2009), p.iv.

Black's Law Dictionary, $8^{\text {th }}$ Ed.

3 Daniel Tarantola, Andrews Byrnes, Michael Johnson, Lynn Kemp Anthony B Zwi \& Sofia Gruskin, 'Human Rights, Health and Development' (2008), Australian Journal of Human Right Vol. 13(2); p.3.

${ }^{4}$ Ozita Eze, Human Rights in Africa, Selected Problems, Lagos, Macmillan (1984) p5, as quoted by Tony Nwazuoke, ibid, at p. 8.

5 Seyi Leigh, 'Constitutional Guarantee for a citizens' Fundamental Right to a Protected Environment: A Comparative Evaluation', (2001) 3 O.O. U Law Journal, 73 at p. 81, where he quoted Chy Ben Ezenekwe, "Teaching Human Rights Education in Multi Cultural Society, paper presented at Workshop on Human Rights Training in the $21^{\text {st }}$ Century The Role of Law Faculties" held on 29 August, 2001 under the auspices' of The Centre for Human Rights, Faculty of Law, University of Lagos, Nigeria.

Ibid. at p. 81.

Seyi Leigh, ibid at p. 81 where he quoted U. O. Umozurike in "Developing Resources for Effective Human Right Teaching", paper presented at Workshop on Human Rights Training in the $21^{\text {st }}$ Century The Role of Law Faculties" held on 29 August, 2001 under the auspices' of The Centre for Human Rights, Faculty of Law, University of Lagos, Nigeria.

${ }^{8}$ M. O. Ogungbe, 'Human Rights and The Law against Prostitution' Contributed in Ogungbe Ed, Nigerian Law: Contemporary Issues, Essays In Honour of Sir, Chief (Dr) G. O. Igbinedion; College of Law, Igbinedion University, Okada, Edo State, Nigeria, (2003), p. 183.

9 John C. Mubangizi, 'Poverty Production and human rights in the African Context', Law Democracy \& Development Vol.11, (2007) p. 2 where he quoted
Piechowak M., "What are human rights? The Concept of Human Rights and their extra-legal justifications in Hanski R. \& Suski M. (Eds), An Introduction to the International Protection of Human Rights (2003) p 3.

${ }^{10}$ John CMubangizi, ibid.

${ }^{11}$ Femi Falana, Fundamental Rights Enforcement, Legal Text Publishing Company Ltd., Lagos, (2004) p.1.

${ }^{12}$ Reinhard Marx, 'A Non - Governmental Human Rights Strategy for Peacekeeping? Netherlands Quarterly of Human Rights, Vol. 14, No.2 June 1996, pg. 129.

${ }^{13}$ Rolf Kunnemann,'The Right to Adequate Food: Violations Related To its Minimum Core Content', contributed in Danie Brand \& Sage Russell (Ed), Exploring The Core Content Of Socio-Economic Rights: South African And International Perspectives, Protea Book House, Pretoria, 2002, pp. 71-72.

${ }^{14}$ (1985) 6 SC 246.

${ }_{15}$ As he then was. He is now retired from the Supreme Court after a meritorious service to the country as one of the country's foremost jurist.

${ }^{16}$ P. 274.

${ }^{17}$ It must be noted that the operating and current Constitution in Nigeria today is the Constitution of the Federa Republic of Nigeria 1999, as amended.

${ }^{18}$ Pp. 274-275.

${ }^{19}$ Fela Anikulapo Kuti was a great Nigerian musician.

${ }^{20}$ Pidgin English is a variant of the official Queens English language commonly spoken in Nigeria; it is less formal in nature.

${ }^{21}$ (2009)2 SC, 55.

${ }^{22}$ At Pgs. $70-71$.

${ }^{23}$ This new rules came into force on $1^{\text {st }}$ December, 2009 and it is titled Fundamental Rights (Enforcement Procedure) Rules, 2009, made under Chapter four of the constitution. It was made in exercise of the powers conferred on the Chief Justice of Nigeria under section 46(3) of the Constitution of Federal Republic of Nigeria, 1999. Hon Justice Idris Legbo Kutigi, CJN., made the Rules.

${ }^{24}$ See Order 1, Rule 2 of the new Rules.

${ }^{25}$ Chapter two of the 1999 Constitution of the Federal Republic of Nigeria (as amended).

${ }^{26}$ Sometimes litigants do this to buy time or prolong issues for reasons best known to them only. This new Rules have time frame within which certain steps must be taken.

${ }^{27}$ Daniel Tarantola, Andrews Byrnes, Michael Johnson, Lynn Kemp Anthony B. Zwi \& Sofia Gruskin,ibid, p.4.

${ }^{28}$ Rolf Kunnermann, ibid, p. 72.

${ }^{29}$ Femi Falana, ibid, at $\mathrm{p} 4$.

${ }^{30}$ Act 108 of 1996.

${ }^{31}$ S.7(1).

${ }^{32} \mathrm{~S} 7(2)$.

${ }^{33}$ Constitution of Ireland, enacted by the people $1^{\text {st }}$ July 1937 , in operation as from $29^{\text {th }}$ December, 1937 , enrolled on 27 May, 1999.

${ }^{34}$ See Art. 40.

${ }^{35}$ Art. 45 of the Irish Constitution state that directive 
principles of social policy shall be cognizable by all courts.

${ }^{36}$ The New Partnership For Africa's Development (NEPAD) is the product of The New African Initiative (NAI) adopted by African leaders in Lusaka, Zambia July 2001, but later renamed NEPAD in Abuja in October 2001.

${ }^{37}$ A few examples of bad governance will suffice, recently the President of the Gambia had to be forced out of office when he refused to comply with the decision of the electorates, an erstwhile President of Ivory Coast was equally forced out of power under similar but not identical circumstances, the then civil wars in Liberia and Sierra-Leone and the war going on in the Sudan region all leaves a bad taste in the mouth.

${ }^{38}$ Editorial, 'UNDP ranks Nigeria $152^{\text {nd }}$ in 2016 Human Development Index', The Daily Times, available at https://dailytimes.ng/news/undp-ranks-nigeria-152nd2016-Humandevelopment-index accessed on 25February,2017., Also the full National Human Development Report, 2016, UNDP, 2016.

39 Some of those existential things that Nigerian are deprived off and which impacts negatively on the protection of human rights include non-payment of pensions and gratuities on time to senior citizens, many of them die while queuing up for this paltry entitlement thus the right to life is infringed upon, access to potable water, affordable Medicare, is a mirage for a lot of people, this one too affects the right to life and right to dignity of human persons, bad roads, lack of proper funding of educational facilities and institutions, just to mention a few, are also impacting negatively on the rights contained in chapter four of the Nigerian Constitution.

${ }^{40}$ John C Mubangizi, 'Poverty production and human rights in the African context' Law, Democracy \& Development, Vol. 11,(2007)p.1.

${ }^{41}$ Legislative judgment is a phrase used by Hon Justice Mobolaji Ojo in a paper titled 'In The Shadow Of Freedom: Reflections On Nigeria's Journey Towards Constitutionalism And The Rule Of Law' delivered at the Nigerian Bar Association, Ijebu Ode Branch 2010 Annual Bar Lecture, Chris Ogunbanjo Centre, Erunwon, Ijebu, on Thursday the $22^{\text {nd }}$ day of July, 2010, p.8 where he reflected on recent happenings in the country and restated the point that it is the sole duty of the judiciary to pronounce judgments on matters brought before it and not the duty of any other organ of government as it had been experienced in a few instances.

${ }^{42}$ See generally The Punch Newspaper, Thursday July 30, The Punch News paper Friday July 31, Vol. 17, No 20,448, pps 1,2\&10.

${ }^{43}$ (2008) ALL FWLR (Pt. 442) p. 1007.

${ }^{44}$ Per Onnoghen, JSC at $\mathrm{p} 1053$.

${ }^{45}$ Oludamilola $v$. State (2010) 5 SCM 166 at pp. 174-175.

${ }^{46}$ Supra.

47 (2008) ALL FWLR (Pt. 440) p. 618.

${ }^{48}$ National Human Rights Commission Act, Cap N46, Laws of The Federation of Nigeria,(LFN), 2004.
${ }^{49}$ See the perambulatory part of the enabling Act.

50 Ibid.

${ }^{51}$ The African Commission on Human and Peoples' Rights is provided for under part ii of the Charter. See Cap A9, Laws of the Federation of Nigeria, 2004.

${ }^{52}$ Preamble, item 3 of the new Rules.

53 Underlining for emphasis.

${ }^{54}$ Underlining for emphasis.

55 Underling for emphasis.

${ }^{56}$ Public interest litigation is defined under the Rules as that which 'includes the interest of Nigerian society or any segment of it in promoting human rights and advancing human rights law'.

57 Underling for emphasis.

${ }_{58}$ Underling for emphasis.

59 Underlining for emphasis.

${ }^{60}$ Footnote 27 supra.

${ }^{61}$ Order 111 of the new rules.

${ }^{62}$ As he was, he is now retired from the Supreme Court of Nigeria.

${ }^{63}$ (2010)3 SCM 85 at 110.

${ }^{64}$ (2009) 3 NWLR (Pt. 1128).

${ }^{65}$ Ibid.

${ }^{66}$ Section 7(1).

${ }^{67}$ Adopted in ROME on 4, November 1950, entry into force 3 September 1953, ogether with its several Protocols.

${ }^{68}$ Adopted and Proclaimed by General Assembly Resolution 217 A(111) of 10 December 1948.

${ }^{69}$ Kurt Mills, 'Reconstructing Sovereignty: A Human Rights Perspective', Netherlands Quarterly Human Rights (NQHR), Vol 15 No 3, Sept 1997 at p. 133 note 37, he quoted Ingrid Delupis, International Law and The Independent State, Crane, Russak, New York, 1974 p. 5.

${ }^{70}$ Ander Mbata, B. Mangu \& Mprariseni Budeli, Democracy and Elections in Africa in the Democratic Republic of Congo:Lessons for Africa' Law Democracy \& Development, Journal of the Faculty of Law of the University of the Western Cape, Vol.12 (2008) 1, p.107, quoting Dugard J. International Law : A South African Perspective, $2^{\text {nd }}$ Ed., (2000) Juta Publishers pp. 240-242.

${ }^{71}$ Kurt Mills, ibid., at p 277 where he quoted Ingrid Delupis, ibid.

${ }^{72}$ Adopted and opened for signature, ratification and accession by General Assembly Resolution 2200 A (XX1) of 16 December 1966, entry into force 3 January 1976.

${ }^{73}$ Adopted and opened for signature, ratification and accession by General Assembly Resolution 2200 A (XX1), Entry into force 23 March 1976.

${ }^{74}$ Adopted and opened for signature and ratification by General Assembly Resolution 2106 of 21 December 1965, entry into force 4 January 1969.

75 Adopted and opened for signature, ratification and accession by General Assembly Resolution 34/180 of 18 December 1979, entry into force 3 September 1981.

${ }^{76}$ Adopted and opened for signature, ratification and accession by General Assembly Resolution 39/46 of 10 December 1984. 
${ }^{77}$ Adopted and opened for signature, ratification and accession by General Assembly Resolution 44/25 of 20 November 1989 entry into force 2 September 1990.

${ }^{78}$ Turin,18 October 1961, entry into force 26 February 1965.

${ }^{79}$ Bogota, 2 May 1948.

${ }^{80}$ Pact of San Jose, Costa Rica, 22 November 1969.

${ }^{81}$ Adopted at the $18^{\text {th }}$ Conference of Heads of State and Government, Nairobi, Kenya, 27 June 1981, entry into force 21 October 1986. The Charter had been domesticated under Nigerian laws as Cap A9, Laws of Fedration of Nigeria, 2004.

${ }^{82}$ This list is by no means exhaustive.

${ }^{83}$ Kurt Mills, 'Reconstructing Sovereignty: A Human Rights Perspective', Netherlands Quarterly of Human Rights (NQHR), Vol. 15, No 3, (1997), p. 267.

${ }^{84}$ Who are either voted into office lawfully or those who seize power and imposed themselves on their people.

${ }^{85}$ MELVIN L MANBO \& GG KOMBONI, 'Promotion of Good Governance and combating corruption and maladministration: the case of Botswana', Law, Democracy \& Development, (Journal of the Faculty of Law of the University of the Western Cape), Vol. 12 May, 2008 (1) Pg.50.

${ }^{86}$ Lysias Dodd Gilbert \& Fidelis Allen, 'Democracy and Good Governance : The Missing Link in Nigeria', Mediterranean Journal of Social Sciences, Vol. 5 No 16 July 2016 , Doi : 10.5901/Mjss.2014v5n16p524 available at http://www.mcser.org/journal/index.php/mjss/article /view/3335, accessed on 25/2/2017.

${ }^{87}$ Charlie Nwekeaku, 'The Rule of Law, Democracy and Good Governance in Nigeria', Global Journal of Political Science and Administration, Vo1.2 No.1 March 2014, available at https://publicadministration.un.org/publications/cont ent/PDFs/E-Library Archives/2007 Public Governance Indicators_a Literature Review accessed on $20 / 2 / 2017$.

${ }^{88}$ Daniel Eseme Gberevbie, 'Democracy, Democratic Institutions And Good Governance in Nigeria' available at http:/ / eprints.covenantuniversity.edu.ng/3676/1/ Democracy\%20and\%20Democratic $\% 20$ Institutions $\% 2$ 0(Published).pdf accessed on 26/2/2017.

${ }^{89}$ See generally, Michael G. Mimicopoulos, 'Public Governance Indicators : A Literature Review', Division for Public Administration and Development Mnagement, Department of Economic and Social Affairs, United Nations, New York.

${ }^{90}$ Daniel Tarantola, Andrews Byrnes, Michael Johnson, Lynn Kemp Anthony B Zwi and Sofia Gruskin, ibid. p.4.

${ }^{91}$ Andre Mbata, B. Mangu \& Mprariseni Budeli, 'Democracy and Elections in Africa in the Democratic Republic of Congo: Lessons for Africa' Law Democracy \& Development, Journal of the Faculty of Law of the University of the Western Cape, Vol.12 (2008) 1, p 103.

${ }^{92}$ Ibid, at p. 104, while quoting Sono $\mathrm{T}$ in "Comments on democracy and its relevance in Africa" (1992) African Perspectives Selection of Works 3; Mangu A. "The Road to Constitutionalism and Democracy in post colonial
Africa" LLD Thesis University of South Africa (2002) 173 ; Romen D, "The Challenges of Democracy in Africa.

${ }^{93}$ Ibid. p. 104.

${ }^{94}$ See generally, the Editorial, Law Democracy \& Development, Journal of the Faculty of Law, University of Western Cape, Vol.12(2008) 1, editorial p.

${ }^{95}$ Fiona Smith, 'Leadership in Human Rights-Leadership for The whole Community' as accesses on www.humanrightscommission.vic.gov.au/newsand events/ speeches/2005067.asp.

${ }^{96}$ Daniel Tarantola, Andrews Byrnes, Michael Johnson, Lynn Kemp Anthony B. Zwi \& Sofia Gruskin, ibid, P.4.

${ }^{97}$ Cecilia Medina, 'Human Rights Must be Brought Back Home', Netherland Quarterly of Human Rights (NQHR), Vol. 15, No3 September 1997, P. 265.

${ }^{98}$ Ibid.

${ }^{99}$ Maria Stavpoulou, "Human Rights and 'Early Warning' in the United Nations", Netherlands Quarterly of Human Rights, Vol 14, No 4, Dec 1996, P.419.

${ }^{100}$ See The Punch Newspaper, Friday August 14, 2009, Vol.17 No.20458, p.2.

${ }^{101}$ New Partnership for Africa's Development, (NEPAD) Para 71.

${ }^{102}$ Ibid. Para. 49; see also Vincent O. Nmehielle, 'The African Union and African Renaissance : A New Era For Human Rights Protection in Africa? , Singapore Journal of International \& Comparative Law, (2003) Vol.7, p.430.

${ }^{103}$ Sandra Liebenberg, 'The Right to Social Security: Response From A South African Perspective', contributed in Danie Brand and Sage Russell (Ed), Exploring the core content of socio-economic rights: South African and international perspectives, Protea Book House, Pretoria, 2002, p.157.

${ }^{104}$ John C Mubangizi, “'Poverty production' and human rights in the African context”, LAW, DEMOCRACY \& DEVELOPMENT, The Journal of the Faculty of Law of the University of Western Cape (2007) 1, Vol.11 p 5.

${ }^{105}$ John C Mubangizi, ibid.

$106 \quad$ Ibid at pgs. $50-51$.

107 Ibid. quoting United Nations, Note by Secretariat "The right to development: Study on existing bilateral and multi-lateral programmes and policies for development partnership" E/CN .4Sub.2/2004/158.

$108 \quad$ Ibid, see footnote 57 supra at pgs.8-9.

${ }^{109}$ Ibid.

${ }^{110}$ Melvin L. Manbo \& GG Komboni, ibid. pp 51-52.

${ }^{111}$ Melvin L. Manbo \& GG Komboni, ibid. at p. 53 where he quoted Boyle B, 'Holding themselves to a higher standard' Sunday Times, 30 April 2006 p. 4.

${ }^{112}$ Melvin L. Manbo \& G. G. Komboni, ibid. pp 53-54.

${ }^{113}$ See the Corrupt Practices and other Related Offences Act, Cap C31, Law Of The Federation of Nigeria (LFN), 2004.

${ }^{114}$ See the Economic and Financial Crimes Commission Act, Cap E1.

${ }^{115}$ This paper does not pretend that it had exhaustively cover 
all the grounds as far as the concepts are concerned.

${ }^{116}$ see www.iss.co.za/AF/Regorg/nepad, see also Declaration on Democracy, Political Economic and Corporate Governance, July 8,2002 Durban South Africa.

${ }^{117}$ Vincent O. Nmehielle, ibid. p.440.

${ }^{118}$ See generally, Vincent O. Nmehielle ibid., p.441.
${ }^{119}$ Trevor Manuel, Forum, 'The need for a human rights culture', LAW, DEMOCRACY \& DEVELOPMENT, (2007) 1, Vol. 11, 85 at pp. 88-89.

${ }^{120}$ Some have stood trials, some are standing trials before the domestic courts of their countries while some are appearing before special courts created by the United Nations for such purposes.

${ }^{121}$ Kurt Mill, ibid, P. 277. 